\title{
Acute and subchronic toxicity evaluation of the hydroethanolic extract of germinated brown rice
}

\author{
Nongporn Hutadilok-Towatana ${ }^{1,2 \star}$, Chatchai Wattanapiromsakul ${ }^{3}$ and \\ Paiboon Thammarutwasik ${ }^{4}$ \\ ${ }^{1}$ Department of Biochemistry, Faculty of Science, Prince of Songkla University, Hat Yai, Thailand. \\ ${ }^{2}$ Natural Products Research Center, Faculty of Science, Prince of Songkla University, Hat Yai, Thailand. \\ ${ }^{3}$ Department of Pharmacognosy and Pharmaceutical Botany, Faculty of Pharmaceutical Sciences, Prince of Songkla \\ University, Hat Yai, Thailand. \\ ${ }^{4}$ Neutraceutical and Functional Food Research and Development Center, Faculty of Agro-Industry, Prince of Songkla \\ University, Hat Yai, Thailand. \\ Accepted 24 July, 2012
}

The hydroethanolic extract obtained from a germinated brown rice (Oryza sativa L. indica) grown under conditions that favor high concentration of $\gamma$-aminobutyric acid (GABA) was evaluated for acute and subchronic toxicities in rodents. Intragastric administration of this extract to Swiss albino mice of both sexes at a single dose of $2 \mathrm{~g} / \mathrm{kg}$ body weight produced no toxicity signs during 7 days of observation. For the subchronic toxicity study, the germinated brown rice extract at 75,150 , and $300 \mathrm{mg} / \mathrm{kg} \mathrm{body}$ weight was administered daily to Wistar rats by oral gavage for 12 weeks. Ten male and ten female rats were used for each dose. In all instances, consumption of the extract showed no adverse effects on behavior, growth or health status of these animals throughout the study period. After 12 weeks of feeding, no significant dose-related differences in blood biochemical parameters were detected among the groups. Hematological profiles of the test groups did not alter from those of the controls. In addition, either gross necropsy or histopathological examination of their visceral organs did not reveal any abnormal appearances. These results suggest that either short or long-term exposure of the extract from GABA-rich germinated brown rice grains may have no negative influence on general well-being of our experimental animals.

Key words: Acute toxicity, brown rice extract, germinated brown rice, subchronic toxicity.

\section{INTRODUCTION}

Rice (Oryza sativa L.) is the main staple food of Asia, making it the second most consumed cereal grain worldwide (Patil and Khan, 2011). Rice is not only a good source of protein and carbohydrate, but it also contains plenty of bioactive substances beneficial for health, which exist mainly in the germ and bran layers of the grain (Juliano, 1992). Generally, rice is milled to improve its

\footnotetext{
${ }^{\star}$ Corresponding author. E-mail: nongporn.t@psu.ac.th or nongporn_towatana@hotmail.com. Tel: +66 (0)74 28 8271. Fax: +66 (04 $4 \overline{4} 6656$.
}

taste and texture before consumption. Milling or polishing process, however, removes the outer bran layer of the rice grain causing a significant decrease in its nutritional and bio-functional components. Despite the fact that the unpolished rice or brown rice has high nutritional value, its intake is unpopular. Unlike the ordinary milled rice or white rice, brown rice requires long cooking time due to the hard texture. Cooked brown rice is also inferior to cooked white rice in terms of both appearance and flavor.

During germination, biochemical activities in rice kernel change drastically in order to produce essential elements and energy for the formation of seedling. As a result, many nutrients and bioactive components are highly 
increased in the germinated rice seeds (Khampang et al., 2009). Germinated brown rice (GBR) is achieved by soaking the whole kernel of brown rice in water until its embryo begins to bud. The process of germination makes GBR much more nutritious than ordinary brown rice as polysaccharides and proteins are hydrolyzed leading to an increase of simple sugars and amino acids in addition to a high production of bio-functional substances, such as $\gamma$-aminobutyric acid (GABA), inositols, $\alpha$-tocopherol, tocotrienols, ferulic acid, and $\gamma$-oryzanol (Kayahara et al., 2001; Komatsuzaki et al., 2007; Moongngarm and Saetang, 2010). The reaction between phytic acid and minerals during the birth of sprout helps soften the texture of GBR and thus causes it to be cooked easily (Kayahara et al., 2001). In comparison to cooked nongerminated brown rice, cooked GBR is sweeter, softer, more swelled, and cohesive (Jiamyangyuen and Oorikul, 2008). Despite the fact that GBR is known for its high nutritional value and biological properties that offer health benefits, the main reason that GBR gains much attention lately is the high GABA content. GABA is a nitrogenous compound produced primarily from decarboxylation of glutamic acid by enzyme glutamate decarboxylase which is highly active in rice seedlings during germination (Liu et al., 2005). In human, its major role as an inhibitory neurotransmitter involving in the regulation of brain functions is well-established (Watanabe et al., 2002). This amino acid derivative also possesses other health effects such as anti-hypertension (Aoki et al., 2003), anticancer (Oh and Oh, 2004), anti-hyperlipidemia (Roohinejad et al., 2010), and lowering blood sugar level (Shallan et al., 2010). Although, biological properties of GBR and its contents, especially GABA, have been extensively studied (Patil and Khan, 2011) and the popularity of GABA and GBR products among healthconscious consumers becomes increased, a systemic toxicological evaluation of GABA derived from GBR for human consumption remains to be established. Earlier study has demonstrated that GBR does not affect the blood parameters in mice (Shirai et al., 2010). In this study, we carried out both acute and subchronic toxicity assays to evaluate the safety of GABA containing extract from germinated brown rice. The data obtained from this study would increase confidence on GBR as well as GABA consumptions.

\section{MATERIALS AND METHODS}

\section{Plant and preparation of GBR extract}

The brown rice grains of a traditional Southern Thailand variety called "Chor Lung" were obtained from Rice Research Center in Pattani province, Thailand. The voucher specimen (SKP 081151901) is kept at the Herbarium of the Faculty of Pharmaceutical Sciences, Prince of Songkla University, Thailand. They were germinated under conditions that give the highest GABA content by soaking in citrate buffer, $\mathrm{pH} 3$ at $40^{\circ} \mathrm{C}$ (Banchuen et al., 2010). After soaking for $72 \mathrm{~h}$, the germinated rice grains were washed with distilled water, and were dried at $50^{\circ} \mathrm{C}$, and then ground to powder. To prepare the extract, $2 \mathrm{~kg}$ of the sample were successively macerated with $1: 1(\mathrm{v} / \mathrm{v})$ of water:ethanol $(3 \mathrm{~L} \times 3$ times). The extract was filtered, concentrated to dryness under reduced pressure, and freeze-dried. Its yield was $0.7 \%(\mathrm{w} / \mathrm{w})$. Dried extract was then stored at $4^{\circ} \mathrm{C}$ in sealed plastic bags and were kept away from light after preparation. The same batch of material was used throughout this study.

\section{Experimental animals}

Swiss albino mice weighing 28 to $35 \mathrm{~g}$ of both sexes and Wistar rats weighing, on average, $200 \mathrm{~g}$ for female and $260 \mathrm{~g}$ for male were obtained from the Laboratory Animal Facility Unit, Faculty of Science, Prince of Songkla University, Hat Yai, Thailand. They were housed in identical wire-mesh-bottomed stainless-steel cages containing 5 or 10 rats per cage and were maintained in an airconditioned room at $25 \pm 2^{\circ} \mathrm{C}, 50$ to $60 \%$ relative humidity, and artificial illumination between 06:00 and 18:00 h. Commercial chow diets (C.P. Mice Feed ${ }^{\circledR}$, Charoen Phokphand Group, Bangkok, Thailand) and drinking water were provided ad libitum. All procedures concerning animal treatments and experimentations in this study were reviewed and approved by the Institutional Committee for Ethical Use of Experimental Animals at Prince of Songkla University (approval no. 2412010).

\section{Acute toxicity study}

The acute toxicity test in this study was performed in Swiss mice using an up and down procedure (Bruce, 1985). Ten mice per sex were randomly assigned to the control and treated groups. The GBR extract dissolved in distilled water was orally given to each mouse in the test groups at a single dose of $2 \mathrm{~g}$ extract $/ \mathrm{kg}$ body weight. The control animals, however, received the water vehicle instead. Following administration, animals were observed closely during the first day, and occasionally, thereafter, for 7 days, for toxic signs and symptoms, and death. At the end of the period, all survivors were sacrificed to examine gross changes in their vital organs.

\section{Subchronic toxicity study}

The method was performed based on the Organization of Economic Co-operation and Development (OECD) guideline for the testing of chemicals: Test No. 408 (OECD, 1998). Male and female Wistar rats were randomly divided into four groups of ten. They were acclimatized for 7 days before beginning the experiments. During the entire 12 weeks, the extract solution prepared as mentioned earlier was administered orally to the animals in each treatment group daily at doses of $0,75,150$, and $300 \mathrm{mg}$ extract $/ \mathrm{kg}$ body weight. The animals were observed daily for their clinical signs and any behavioral changes. They were weighed initially and then once a week until termination.

At the end of the study, the rats were anesthetized with ether following an overnight fasting. Their blood was collected by heart puncture for hematology and biochemical analyses. All hematological measurements were performed by an automatic analyzer of Nihon Kohden Model Celltac E (MEK-7222) (Nihon Kohden Corp., Tokyo, Japan). Plasma samples were assayed for their biochemical levels using a BioSystems Lab Automation Model A15 (BioSystems S.A., Barcelona, Spain).

Each rat was sacrificed by cervical dislocation and then an autopsy was performed. The heart, liver, spleen, and kidneys were macroscopically observed and weighed immediately after removal. Samples of these organs were fixed in $10 \%(\mathrm{v} / \mathrm{v})$ neutral buffered formalin and were kept in the solution for further histopathological 
examination.

\section{Statistical analysis}

All data are presented as means \pm standard error of mean (SEM). They were subjected to one-way analysis of variance (ANOVA) and differences between means were evaluated by Duncan's multiple range test at $95 \%$ confidence level. Significance was judged at $\mathrm{P} \leq$ 0.05 .

\section{RESULTS}

\section{Acute toxicity study}

All mice treated with the GBR extract at a single dose of $2 \mathrm{~g} / \mathrm{kg}$ body weight by intragastric gavage survived until the end of experimental period. They did not exhibit any signs of toxicity during the 7 days of observation. There were no obvious differences between the treated and untreated animals. The gross examinations of their internal organs also found no pathological abnormalities.

\section{Subchronic toxicity study}

Ingestion of the extract at any tested dose did not cause mortality or toxic symptoms in the rats. The average daily food and water intake among the groups of each sex were similar throughout this study. There was no unusual behavior or physical appearance among these animals. In all cases, their feces were dry and dark indicating no abnormalities in their digestive tracts. Measurements of the body weight over the whole experimental period found no differences among the four male groups at any time point (Figure 1). The female rats, however, hardly gained weight as the experiment progressed. Between the control and treatment groups, their rates of weight increase were not significantly different (Figure 1).

As shown in Table 1, feeding of the extract up to the highest dose of $300 \mathrm{mg} / \mathrm{kg} /$ day for consecutive 12 weeks did not produce any significant dose-related effects on blood chemistry parameters in female rats. In male groups receiving the extract at low dose $(75 \mathrm{mg} / \mathrm{kg} /$ day $)$ and middle dose (150 mg/kg/day), however, their plasma triglycerides, cholesterol, and aspartate aminotransferase (AST) concentrations were markedly increased from the control values at the end of the treatment $(P \leq 0.05)$, whereas protein, blood urea nitrogen (BUN), and uric acid levels were slightly but significantly higher $(P \leq 0.05)$ (Table 1).

To determine if the extract could affect blood cells and the bone marrow activity of the rats, hematological examinations were performed. As presented in Table 2, plasma of both male and female groups receiving the extract at low and middle doses contained more platelets, but significant differences were not found among groups $(P>0.05)$. Also, eosinophil counts in all treated female groups seem to become lower with increasing doses, but they were not significantly different from the control value $(P>0.05)$. Despite the mentioned changes, no hemolyzed plasma was obtained and normal blood smears were observed in all of the animals.

At autopsy, macroscopic examinations of vital organs including heart, liver, kidney, and spleen in our experimental rats did not show any abnormality in their gross appearances and weights as a result of the consumption of the extract (Table 3). In addition, we did not detect any damage in their gastrointestinal tracts, the potential and direct target for toxic effects of ingested foods. The results from gross examination were also confirmed by histopathological assessment. The extract did not produce any significant histological changes in the organ tissues of any of the animals (Figure 2).

\section{DISCUSSION}

In this study, the GABA containing extract was prepared from germinated grains of "Chor Lung", one of the popular traditional rice varieties planted in Southern Thailand (Rice Department, Ministry of Agriculture and Cooperatives, Thailand, available at http://ricethailand.go.th). The results of our acute toxicity study indicate that this GBR extract is non-toxic to mice after they have been exposed for short time to a high dosage. In the subchronic experiments, rats were given the extract up to $300 \mathrm{mg} / \mathrm{kg} /$ day which is four-fold higher than the level obtained from an estimated human consumption (50 g brown rice/ $\mathrm{kg} /$ day). During the 12 week-period, we did not observe any treatmentassociated effects on the body weights of both male and female rats suggesting that the extract did not alter their metabolic rates or improved digestion and absorption of foods in these animals. In a previous study, Oh et al. (2005) found that the intake of GBR water extract containing 841 nmoles of $\mathrm{GABA} / \mathrm{ml}$ for 8 weeks effectively reduces abdominal fat without lowering the weight and rate of weight increase in mice fed a high fat diet. Although, the water extract of GBR as well as the whole GBR improve the serum lipid profiles in high fat diet-induced hyperlipidemic animals (Oh et al., 2005; Miura et al., 2006; Roohinejad et al., 2010), GBR intake does not reduce plasma lipids in normal mice (Shirai et al., 2010). In the present study, we did not observed any significantly different blood lipid results among our female rats. The measurably increased amount of plasma triglycerides in both male groups is unknown. It could have been the results of biological variation among rats rather than the treatment effect, because their dose levels did not vary with the extract doses and were still within the reference intervals for Wistar rats (Boehm et al., 2007). Our finding that GBR extract did not suppress plasma lipids when animals were not fed additional fat is in agreement with that of Shirai et al. (2010), and thus suggests that a reduction in blood lipids found in animals 

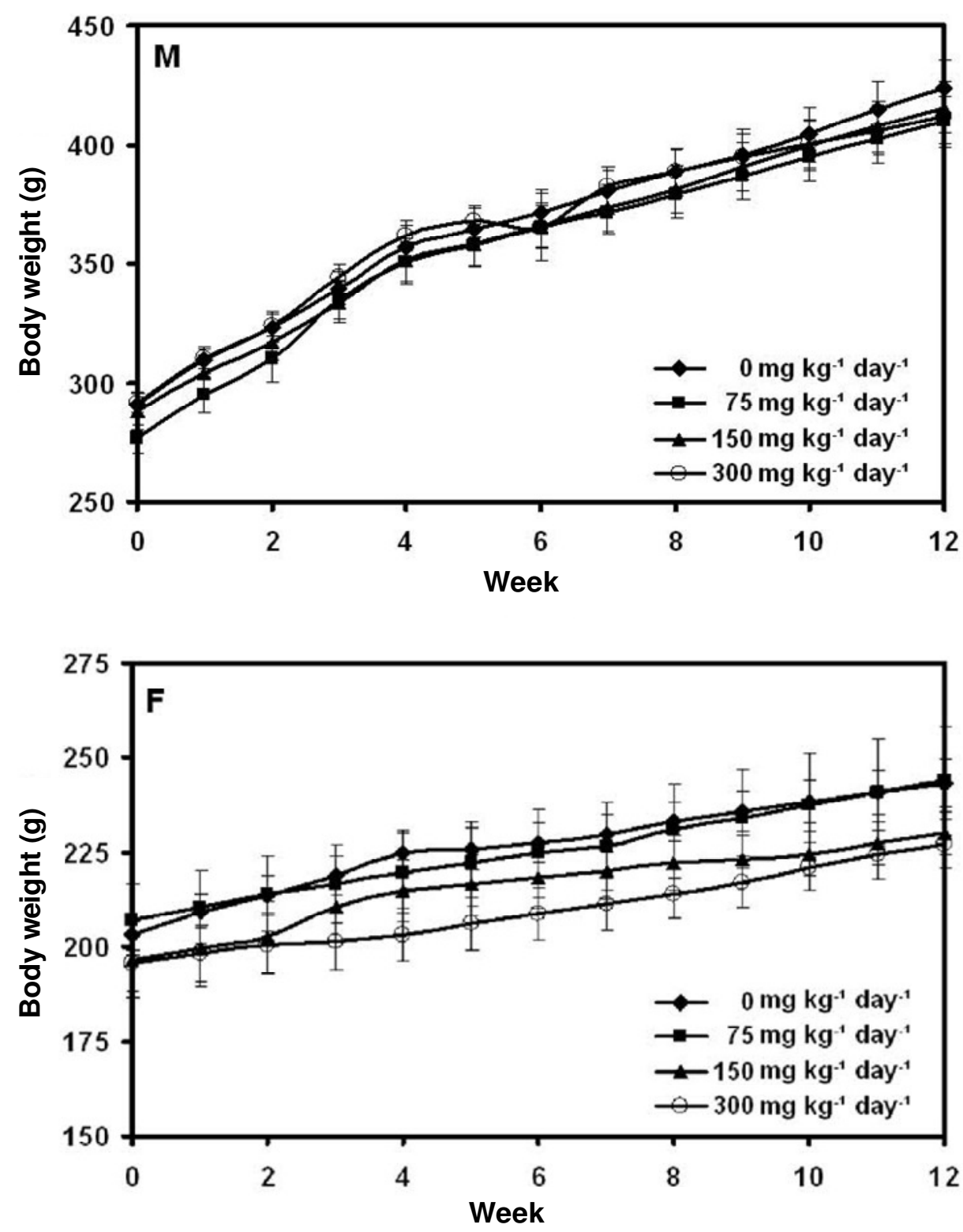

Figure 1. Body weights of male $(\mathrm{M})$ and female $(\mathrm{F})$ rats fed daily for 12 weeks with the hydroethanolic extract of germinated brown rice at various doses. Values are mean $\pm S D ; n$ $=10$. The body weights of untreated female group at the 4 to 12th week and those of all male groups at the 3 to 12 th week were significantly different $(P \leq 0.05)$ from their corresponding initial values.

fed a high fat diet may be due to inhibitory effects of some ingredient(s) rather than GABA in GBR on dietary fat absorption. Hypoglycemic action of GBR on postprandial blood in healthy subjects has been reported (Ito et al., 2005; Seki et al., 2005; Shallan et al., 2010) and insoluble fiber in GBR has been suggested to be mainly responsible for such effect (Seki et al., 2005). However, GBR intake does not decrease fasting blood glucose in normal mice (Shirai et al., 2010). The same evidence was also observed in this study. Therefore, it is conceivable that GBR intake would lower blood glucose concentration by suppressing its absorption from the diet. In diabetes, the hypoglycemic effects of GBR have been reported (Hagiwara et al., 2004; Hsu et al., 2008) and acylated steryl glucoside has been proposed to be an active ingredient in this case (Usuki et al., 2008).

AST (serum glutamic oxaloacetic transaminase (SGOT)) is commonly measured clinically as a part of diagnostic liver function tests. This enzyme is found in the liver, heart, skeletal muscle, kidneys, brain, and red blood cells. As a result, its level in plasma may be elevated in diseases affecting these organs and is less specific 
Table 1. Blood chemistry values in rats treated with the germinated brown extract at various doses for 12 weeks.

\begin{tabular}{|c|c|c|c|c|}
\hline \multirow{2}{*}{ Parameter } & \multicolumn{4}{|c|}{ Administered doses ( $\mathrm{mg} / \mathrm{kg} /$ day) } \\
\hline & 0 (Control) & 75 & 150 & 300 \\
\hline \multicolumn{5}{|l|}{ Male rats } \\
\hline Glucose (mg/dl) & $88.50 \pm 3.72^{\mathrm{a}}$ & $75.44 \pm 5.50^{\mathrm{a}}$ & $66.71 \pm 10.52^{\mathrm{a}}$ & $86.00 \pm 5.08^{\mathrm{a}}$ \\
\hline BUN (mg/dl) & $26.46 \pm 1.45^{\mathrm{c}}$ & $21.24 \pm 1.27^{\mathrm{a}}$ & $21.80 \pm 0.94^{\mathrm{ab}}$ & $25.03 \pm 0.77^{\mathrm{bc}}$ \\
\hline Creatinine (mg/dl) & $0.64 \pm 0.02^{b c}$ & $0.68 \pm 0.04^{c}$ & $0.43 \pm 0.46^{\mathrm{a}}$ & $0.56 \pm 0.03^{b}$ \\
\hline Cholesterol (mg/dl) & $54.00 \pm 4.26^{\mathrm{a}}$ & $77.00 \pm 5.83^{\mathrm{c}}$ & $69.88 \pm 5.97^{b c}$ & $60.40 \pm 3.62^{\mathrm{a}}$ \\
\hline Triglycerides (mg/dl) & $47.70 \pm 3.50^{\mathrm{a}}$ & $90.56 \pm 10.73^{b}$ & $82.00 \pm 16.40^{b}$ & $52.10 \pm 3.66^{\mathrm{a}}$ \\
\hline $\mathrm{HDL}-\mathrm{C}(\mathrm{mg} / \mathrm{dl})$ & $42.30 \pm 4.07^{\mathrm{a}}$ & $40.22 \pm 4.99^{\mathrm{a}}$ & $42.33 \pm 7.33^{\mathrm{a}}$ & $32.56 \pm 2.49^{a}$ \\
\hline Total protein $(\mathrm{g} / \mathrm{dl})$ & $7.10 \pm 0.11^{\mathrm{a}}$ & $8.29 \pm 0.12^{C}$ & $7.75 \pm 0.23^{b}$ & $7.10 \pm 0.10^{\mathrm{a}}$ \\
\hline Total bilirubin (mg/dl) & $0.50 \pm 0.07^{\mathrm{a}}$ & $0.53 \pm 0.08^{\mathrm{a}}$ & $0.75 \pm 0.22^{\mathrm{a}}$ & $0.42 \pm 0.10^{\mathrm{a}}$ \\
\hline AST (U/L) & $191.80 \pm 9.78^{\mathrm{a}}$ & $257.00 \pm 16.18^{b}$ & $239.38 \pm 15.14^{b}$ & $178.00 \pm 8.71^{\mathrm{a}}$ \\
\hline $\mathrm{ALT}(\mathrm{U} / \mathrm{L})$ & $45.90 \pm 2.84^{a}$ & $43.44 \pm 1.44^{\mathrm{a}}$ & $47.75 \pm 4.84^{\mathrm{a}}$ & $51.70 \pm 4.44^{\mathrm{a}}$ \\
\hline ALP (U/L) & $65.10 \pm 2.48^{\mathrm{a}}$ & $61.44 \pm 2.65^{\mathrm{a}}$ & $76.13 \pm 14.17^{\mathrm{a}}$ & $67.70 \pm 3.53^{\mathrm{a}}$ \\
\hline Albumin (g/dl) & $3.49 \pm 0.04^{\mathrm{a}}$ & $3.86 \pm 0.04^{\mathrm{b}}$ & $3.52 \pm 0.26^{\mathrm{a}}$ & $3.47 \pm 0.06^{\mathrm{a}}$ \\
\hline Uric acid (mg/dl) & $1.20 \pm 0.15^{\mathrm{a}}$ & $1.92 \pm 0.14^{b}$ & $1.99 \pm 0.20^{b}$ & $1.56 \pm 0.12^{\mathrm{ab}}$ \\
\hline \multicolumn{5}{|l|}{ Female rats } \\
\hline Glucose (mg/dl) & $68.30 \pm 4.48^{\mathrm{a}}$ & $131.83 \pm 24.42^{b}$ & $55.50 \pm 9.43^{\mathrm{a}}$ & $72.00 \pm 6.99^{a}$ \\
\hline BUN (mg/dl) & $27.85 \pm 1.71^{\mathrm{a}}$ & $22.33 \pm 5.58^{\mathrm{a}}$ & $30.40 \pm 5.79^{\mathrm{a}}$ & $24.72 \pm 1.49^{\mathrm{a}}$ \\
\hline Creatinine (mg/dl) & $0.74 \pm 0.10^{\mathrm{b}}$ & $0.43 \pm 0.10^{\mathrm{a}}$ & $0.73 \pm 0.05^{\mathrm{b}}$ & $0.58 \pm 0.02^{\mathrm{ab}}$ \\
\hline Cholesterol (mg/dl) & $50.30 \pm 4.41^{\mathrm{a}}$ & $85.43 \pm 22.78^{a}$ & $103.12 \pm 43.76^{\mathrm{a}}$ & $75.50 \pm 7.32^{\mathrm{a}}$ \\
\hline Triglycerides (mg/dl) & $52.90 \pm 4.12^{\mathrm{a}}$ & $83.50 \pm 21.79^{\mathrm{a}}$ & $212.88 \pm 37.31^{\mathrm{a}}$ & $60.60 \pm 5.62^{\mathrm{a}}$ \\
\hline $\mathrm{HDL}-\mathrm{C}(\mathrm{mg} / \mathrm{dl})$ & $47.10 \pm 4.00^{\mathrm{a}}$ & $28.00 \pm 0.00^{\mathrm{a}}$ & $28.25 \pm 5.15^{\mathrm{a}}$ & $35.78 \pm 4.64^{\mathrm{a}}$ \\
\hline Total Protein (g/dl) & $7.19 \pm 0.26^{\mathrm{a}}$ & $5.20 \pm 1.09^{\mathrm{a}}$ & $11.03 \pm 3.69^{\mathrm{a}}$ & $7.22 \pm 0.92^{\mathrm{a}}$ \\
\hline Total Bilirubin (mg/dl) & $0.82 \pm 0.19^{a}$ & $1.18 \pm 0.43^{\mathrm{a}}$ & $0.68 \pm 0.43^{\mathrm{a}}$ & $0.78 \pm 0.33^{\mathrm{a}}$ \\
\hline AST (U/L) & $157.40 \pm 8.70^{\mathrm{a}}$ & $151.67 \pm 55.27^{\mathrm{a}}$ & $216.20 \pm 15.63^{\mathrm{a}}$ & $164.33 \pm 13.84^{a}$ \\
\hline $\mathrm{ALT}(\mathrm{U} / \mathrm{L})$ & $53.10 \pm 9.65^{a}$ & $134.50 \pm 85.34^{\mathrm{a}}$ & $32.83 \pm 5.48^{\mathrm{a}}$ & $34.67 \pm 2.68^{\mathrm{a}}$ \\
\hline $\operatorname{ALP}(\mathrm{U} / \mathrm{L})$ & $35.40 \pm 1.92^{\mathrm{a}}$ & $35.50 \pm 5.32^{\mathrm{a}}$ & $34.17 \pm 3.82^{\mathrm{a}}$ & $39.67 \pm 4.18^{\mathrm{a}}$ \\
\hline Albumin (g/dl) & $3.62 \pm 0.07^{b}$ & $2.70 \pm 0.86^{\mathrm{a}}$ & $4.19 \pm 0.28^{b}$ & $3.71 \pm 0.54^{b}$ \\
\hline Uric Acid (mg/dl) & $1.99 \pm 0.34^{\mathrm{a}}$ & $2.03 \pm 0.34^{a}$ & $2.42 \pm 0.54^{\mathrm{a}}$ & $1.58 \pm 0.11^{\mathrm{a}}$ \\
\hline
\end{tabular}

$\mathrm{AST}=$ aspartate aminotransferase, $\mathrm{ALT}=$ alanine aminotransferase, $\mathrm{ALP}=$ alkaline phosphatase, $\mathrm{BUN}=$ blood urea nitrogen, and $\mathrm{HDL}-\mathrm{C}=$ high density lipoprotein-cholesterol. Values are mean \pm SEM, $n=8$ to 10. Values with different superscripts ( $a, b, c)$ in the same row are significantly different $(\mathrm{P} \leq 0.05)$.

indicator than alanine aminotransferase (ALT; serum glutamic pyruvic transaminase (SGPT)) for hepatocellular damage (Rej, 1989). In our study, we found increased AST in plasma of male rats receiving the extract at 75 and $150 \mathrm{mg} / \mathrm{kg} /$ day as compared to the control animals. The reason behind these findings remains unknown. Since the differences were not dose-related and did not appear in female groups, they are not likely to be treatment-associated. Also, the alterations of plasma proteins, BUN, and uric acid values among our male rats were not dose-dependent. The effects were also slight and thus seem to have no clinical implication. Despite the aforementioned changes, their heart, liver, and kidneys did not reveal any abnormalities after histopathological examinations.
In this study, the hematological values detected in all blood samples appeared to be within the normal range and lymphocytes which are the central cells of the immune system, were the major leukocyte count (white blood cell, WBC) populations as reported in the literature (Matsuda et al., 2000). Previously, immune cellstimulating activities of GBR extracts have been demonstrated in mice (Oh and Oh, 2003). A preliminary study of our GBR extract on nitric oxide production in cultured macrophages however revealed that it had antiinflammatory activity and hydroxyphenyllactic acid could be one of candidate components for such inhibitory action.

The increased circulating platelets detected in low-dose and middle-dose groups of both sexes are probably 
Table 2. Hematological values in rats treated with the germinated brown rice extract at various doses for 12 weeks.

\begin{tabular}{|c|c|c|c|c|}
\hline \multirow{2}{*}{ Parameter } & \multicolumn{4}{|c|}{ Administered doses (mg/kg/day) } \\
\hline & 0 (Control) & 75 & 150 & 300 \\
\hline \multicolumn{5}{|l|}{ Male rats } \\
\hline WBC $(\mu /)$ & $5,680.0 \pm 214.9^{\mathrm{a}}$ & $5,677.8 \pm 462.4^{a}$ & $7,575.0 \pm 2,403.4^{a}$ & $5,510.0 \pm 502.9^{a}$ \\
\hline $\mathrm{HB}(\mathrm{g} / \mathrm{dl})$ & $14.81 \pm 0.19^{\mathrm{ab}}$ & $16.03 \pm 0.22^{\mathrm{C}}$ & $15.46 \pm 0.55^{b c}$ & $14.48 \pm 0.27^{\mathrm{a}}$ \\
\hline $\mathrm{HCT}(\%)$ & $43.50 \pm 0.69^{\mathrm{ab}}$ & $47.56 \pm 0.44^{c}$ & $45.38 \pm 1.59^{\mathrm{bc}}$ & $42.20 \pm 0.83^{\mathrm{a}}$ \\
\hline MCV (fL) & $52.50 \pm 0.22^{\mathrm{ab}}$ & $54.00 \pm 0.53^{b}$ & $52.88 \pm 0.61^{\mathrm{ab}}$ & $51.40 \pm 0.60^{\mathrm{a}}$ \\
\hline $\mathrm{MCH}(\mathrm{pg})$ & $18.00 \pm 0.00^{\mathrm{a}}$ & $18.22 \pm 0.22^{a}$ & $18.00 \pm 0.19^{a}$ & $17.60 \pm 0.27^{\mathrm{a}}$ \\
\hline $\mathrm{MCHC}(\mathrm{g} / \mathrm{dl})$ & $34.20 \pm 0.13^{\mathrm{a}}$ & $33.78 \pm 0.22^{\mathrm{a}}$ & $34.33 \pm 0.24^{\mathrm{a}}$ & $34.10 \pm 0.31^{\mathrm{a}}$ \\
\hline PMN (\%) & $70.00 \pm 1.25^{\mathrm{a}}$ & $73.33 \pm 1.17^{\mathrm{a}}$ & $70.75 \pm 1.63^{\mathrm{a}}$ & $68.40 \pm 2.09^{a}$ \\
\hline Lymp (\%) & $27.30 \pm 1.27^{\mathrm{a}}$ & $24.33 \pm 1.12^{\mathrm{a}}$ & $25.63 \pm 1.41^{\mathrm{a}}$ & $28.50 \pm 1.70^{\mathrm{a}}$ \\
\hline Mono (\%) & $1.30 \pm 0.15^{\mathrm{a}}$ & $1.22 \pm 0.15^{\mathrm{a}}$ & $2.13 \pm 0.40^{\mathrm{a}}$ & $2.10 \pm 0.50^{\mathrm{a}}$ \\
\hline Eo $(\%)$ & $1.40 \pm 0.22^{\mathrm{a}}$ & $1.11 \pm 0.20^{\mathrm{a}}$ & $1.50 \pm 0.33^{\mathrm{a}}$ & $1.00 \pm 0.15^{\mathrm{a}}$ \\
\hline Baso (\%) & $0.00 \pm 0.00^{\mathrm{a}}$ & $0.00 \pm 0.00^{\mathrm{a}}$ & $0.00 \pm 0.00^{\mathrm{a}}$ & $0.00 \pm 0.00^{\mathrm{a}}$ \\
\hline PIt $(\mu / L)$ & $561,300 \pm 21,687^{a}$ & $770,625 \pm 27,306^{a}$ & $728,750 \pm 52,925^{a}$ & $561,600 \pm 45,553^{a}$ \\
\hline $\operatorname{RBC}(\mu / L)$ & $8,252,000 \pm 153,947^{a}$ & $8,796,667 \pm 121,747^{a}$ & $8,591,250 \pm 327,080^{a}$ & $8,249,000 \pm 146,799^{a}$ \\
\hline \multicolumn{5}{|l|}{ Female rats } \\
\hline WBC $(\mu / L)$ & $3,070.0 \pm 282.5^{a}$ & $4,080.0 \pm 377.4^{a}$ & $3,188.9 \pm 524.3^{a}$ & $4,250.0 \pm 571.2^{\mathrm{a}}$ \\
\hline $\mathrm{HB}(\mathrm{g} / \mathrm{dl})$ & $14.07 \pm 0.47^{\mathrm{a}}$ & $15.00 \pm 0.47^{\mathrm{a}}$ & $15.30 \pm 0.36^{\mathrm{a}}$ & $14.23 \pm 0.30^{\mathrm{a}}$ \\
\hline HCT (\%) & $39.90 \pm 1.36^{a}$ & $42.30 \pm 1.25^{a}$ & $43.00 \pm 0.82^{a}$ & $40.80 \pm 1.07^{a}$ \\
\hline MCV (fL) & $53.90 \pm 0.46^{\mathrm{a}}$ & $55.30 \pm 0.47^{a}$ & $52.44 \pm 2.16^{\mathrm{a}}$ & $53.00 \pm 0.33^{\mathrm{a}}$ \\
\hline $\mathrm{MCH}(\mathrm{pg})$ & $19.00 \pm 0.21^{\mathrm{a}}$ & $21.70 \pm 2.04^{\mathrm{a}}$ & $19.00 \pm 0.36^{a}$ & $19.00 \pm 0.33^{\mathrm{a}}$ \\
\hline $\mathrm{MCHC}(\mathrm{g} / \mathrm{dl})$ & $35.40 \pm 0.22^{\mathrm{a}}$ & $35.70 \pm 0.30^{\mathrm{a}}$ & $35.67 \pm 0.44^{\mathrm{a}}$ & $35.70 \pm 0.65^{\mathrm{a}}$ \\
\hline PMN (\%) & $68.60 \pm 1.59^{a}$ & $69.00 \pm 2.56^{a}$ & $68.89 \pm 1.40^{a}$ & $73.40 \pm 0.79^{a}$ \\
\hline Lymp (\%) & $26.10 \pm 1.38^{\mathrm{a}}$ & $26.30 \pm 2.54^{\mathrm{a}}$ & $27.44 \pm 1.82^{\mathrm{a}}$ & $23.80 \pm 1.08^{\mathrm{a}}$ \\
\hline Mono (\%) & $2.20 \pm 0.49^{\mathrm{a}}$ & $2.50 \pm 0.62^{\mathrm{a}}$ & $1.89 \pm 0.31^{\mathrm{a}}$ & $1.80 \pm 0.55^{\mathrm{a}}$ \\
\hline Eo $(\%)$ & $3.00 \pm 0.54^{a}$ & $2.20 \pm 0.59^{a}$ & $1.78 \pm 0.40^{\mathrm{a}}$ & $1.00 \pm 0.47^{\mathrm{a}}$ \\
\hline Baso (\%) & $0.10 \pm 0.10^{\mathrm{a}}$ & $0.00 \pm 0.00^{\mathrm{a}}$ & $0.00 \pm 0.00^{\mathrm{a}}$ & $0.00 \pm 0.00^{\mathrm{a}}$ \\
\hline PIt $(\mu / L)$ & $549,500 \pm 70,107^{\mathrm{a}}$ & $742,000 \pm 77,419^{\mathrm{a}}$ & $800,890 \pm 10,578^{a}$ & $616,400 \pm 70,434^{\mathrm{a}}$ \\
\hline $\operatorname{RBC}(\mu / L)$ & $7,406,000 \pm 260,888^{a}$ & $7,661,000 \pm 265,173^{a}$ & $7,735,600 \pm 245,821^{a}$ & $7,697,000 \pm 197,130^{\mathrm{a}}$ \\
\hline
\end{tabular}

$\mathrm{WBC}=$ leukocyte count, $\mathrm{HB}=$ hemoglobin concentration, $\mathrm{HCT}=$ hematocrit, $\mathrm{MCV}=$ mean corpuscular volume, $\mathrm{MCH}=\mathrm{mean}$ corpuscular hemoglobin, $\mathrm{MCHC}=$ mean corpuscular hemoglobin concentration, $\mathrm{PMN}=$ polymorphonuclear leukocyte, Lymp = lymphocyte, Mono = monocyte, $\mathrm{Eo}=$ eosinophil, Baso $=$ basophil, $\mathrm{PIt}=$ platelet count, and RBC $=$ erythrocyte count. Values are mean $\pm \mathrm{SEM}, \mathrm{n}=8$ to 10 . Values with different superscripts $(a, b, c)$ in the same row are significantly different $(P \leq 0.05)$.

transient since it did not occur in the high-dose group and the differences were significant only among the male groups. In the female groups, however, decreased eosinophil counts are likely to be treatment-associated due to their dose-variable manner, but need to be further investigated.

In conclusion, we have investigated both acute and subchronic toxicities of the extract from GABA-rich GBR of a Southern Thailand variety. With respect to our results, the extract at the doses tested did not produce any significant undesirable effects in the experimental animals. Their livers and kidneys which are the most sensitive organs to toxic factors were apparently normal and showed no signs of dysfunction. The toxicological data obtained from this study are of significance in relation to increasing the consumption of GBR and its products for health benefits and remedial purposes worldwide. An additional study to evaluate chronic toxicity is needed to determine the long-term safety of the same kind of rice extract.

\section{ACKNOWLEDGEMENTS}

The authors are grateful to Thailand Research Fund and Prince of Songkla University for their financial supports (Grant No. DBG5080023). The authors thank Miss Worrapanit Chansuwan for performing statistical analyses of all the data obtained and Dr. Brian Hodgson for reading our manuscript. 
Table 3. Organ weights in rats treated with the germinated brown rice extract at various doses for 12 weeks.

\begin{tabular}{lcccc}
\hline \multirow{2}{*}{ Organ weight $\mathbf{( g )}$} & \multicolumn{4}{c}{ Administered doses (mg/kg/day) } \\
\cline { 2 - 5 } & $\mathbf{0}$ (Control) & $\mathbf{7 5}$ & $\mathbf{1 5 0}$ & $\mathbf{3 0 0}$ \\
\hline Male rats & & & & \\
Liver & $8.95 \pm 0.46^{\mathrm{a}}$ & $7.99 \pm 0.23^{\mathrm{a}}$ & $8.17 \pm 0.32^{\mathrm{a}}$ & $8.90 \pm 0.29^{\mathrm{a}}$ \\
Kidney & $2.02 \pm 0.07^{\mathrm{a}}$ & $1.91 \pm 0.08^{\mathrm{a}}$ & $1.84 \pm 0.06^{\mathrm{a}}$ & $2.02 \pm 0.06^{\mathrm{a}}$ \\
Heart & $1.29 \pm 0.05^{\mathrm{a}}$ & $1.25 \pm 0.06^{\mathrm{a}}$ & $1.28 \pm 0.06^{\mathrm{a}}$ & $1.26 \pm 0.05^{\mathrm{a}}$ \\
Spleen & $0.73 \pm 0.02^{\mathrm{a}}$ & $0.67 \pm 0.04^{\mathrm{a}}$ & $0.69 \pm 0.05^{\mathrm{a}}$ & $0.67 \pm 0.03^{\mathrm{a}}$ \\
& & & & \\
Female rats & & & & \\
Liver & $5.84 \pm 0.18^{\mathrm{a}}$ & $5.20 \pm 0.20^{\mathrm{b}}$ & $5.26 \pm 0.22^{\mathrm{b}}$ & $5.28 \pm 0.14^{\mathrm{b}}$ \\
Kidney & $1.40 \pm 0.05^{\mathrm{a}}$ & $1.31 \pm 0.05^{\mathrm{ab}}$ & $1.31 \pm 0.04^{\mathrm{b}}$ & $1.25 \pm 0.03^{\mathrm{b}}$ \\
Heart & $0.83 \pm 0.02^{\mathrm{a}}$ & $0.84 \pm 0.03^{\mathrm{a}}$ & $0.84 \pm 0.03^{\mathrm{a}}$ & $0.80 \pm 0.04^{\mathrm{a}}$ \\
Spleen & $0.55 \pm 0.02^{\mathrm{a}}$ & $0.50 \pm 0.03^{\mathrm{a}}$ & $0.59 \pm 0.08^{\mathrm{a}}$ & $0.52 \pm 0.02^{\mathrm{a}}$ \\
\hline
\end{tabular}

Values are mean \pm SEM, $n=9$ to 10 . Values with different superscripts $(a, b)$ in the same row are significantly different $(P \leq 0.05)$.

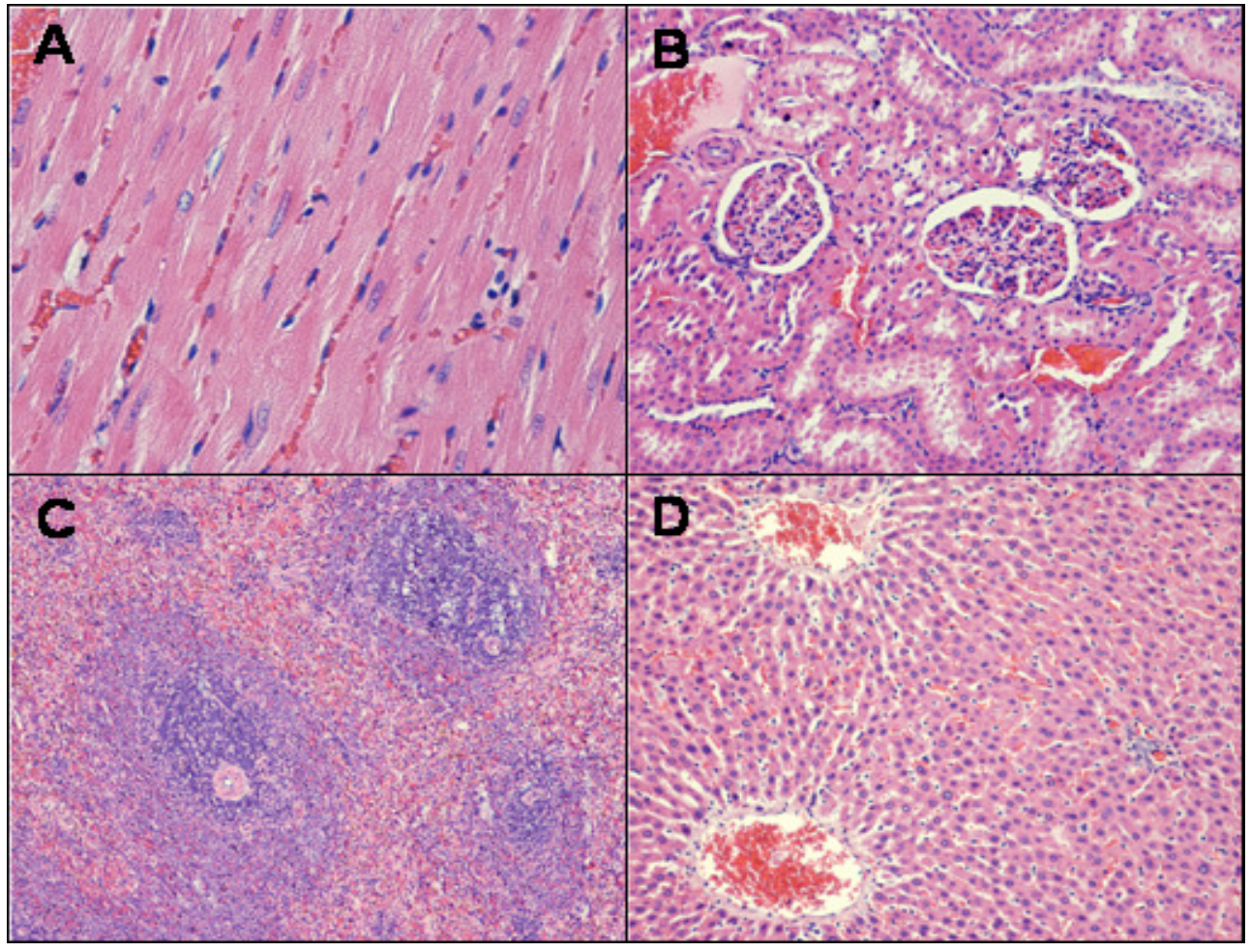

Figure 2. The histological morphology of internal organs of a male rat treated with extract at 300 $\mathrm{mg} / \mathrm{kg} /$ day dosage, as shown by hematoxylin and eosin staining. (A) Heart (magnification, $\times 40$ ); (B) kidney (magnification, $\times 40$ ); (C) spleen (magnification, $\times 10$ ); (D) liver (magnification, $\times 10$ ).

\section{REFERENCES}

Aoki H, Furuya $\mathrm{Y}$, Endo $\mathrm{Y}$, Fujimoto $\mathrm{K}$ (2003). Effect of gammaaminobutyric acid-enriched tempeh-like fermented soy bean (GABATempeh) on the blood pressure of spontaneous hypertensive rats. Biosci. Biotechnol. Biochem. 67:1806-1808.

Banchuen J, Thammarutwasik $P$, Ooraikul B, Wuttijumnong $P$, Sirivongpaisal P (2010). Increasing the bio-active compounds contents by optimizing the germination conditions of Southern Thai brown rice. Songklanakarin J. Sci. Technol. 32:219-230.

Boehm O, Zur B, Koch A, Tran N, Freyenhagen R, Hartmann M, Zacharowski K (2007). Erratum: Clinical chemistry reference database for Wistar rats and C57/BL6 mice. Biol. Chem. 388:12551256.

Bruce RD (1985). An up- and down procedure for acute toxicity testing. Fundam. Appl. Toxicol. 5:151-157. 
Hagiwara H, Seki T, Ariga T (2004). The effect of pre-germinated brown rice intake on blood glucose and PAI-1 levels in streptozotocininduced diabetic rats. Biosci. Biotechnol. Biochem. 68:444-447.

Hsu TF, Kise M, Wang MF, Ito Y, Yang MD, Aoto H, Yoshihara R, Yokoyama J, Kunii D, Yamamoto S (2008). Effects of pre-germinated brown rice on blood glucose and lipid levels in free-living patients with impaired fasting blood glucose or type 2 diabetes. J. Nutr. Sci. Vitaminol. 54:163-168.

Ito $\mathrm{Y}$, Mizukuchi A, Kise $\mathrm{M}$, Aoto $\mathrm{H}$, Yamamoto $\mathrm{S}$, Yoshihara $\mathrm{R}$, Yokoyama J (2005). Postprandial blood glucose and insulin responses to pre-germinated brown rice in healthy subjects. J. Med. Invest. 52:159-164.

Jiamyangyuen S, Oorikul B (2008). The physico-chemical, eating and sensorial properties of germinated brown rice. J. Food Agric. Environ. 6:119-124.

Juliano BO (1992). Structure, chemistry and function of rice grain and its fraction. Cereal Food World 37:772-774.

Kayahara H, Tsukahara K, Tatai T (2001). Flavor, health and nutritional quality of pre-germinated brown rice. In: Spanier et al. (eds.) Food, Flavor and Chemistry: Advances of the New Millennium, The Royal Society of Chemistry, UK, pp. 546-551.

Khampang E, Kerdchoechuen O, Laohaka N (2009). Change of chemical composition of rice and cereals during germination. Agric. Sci. J. 40:341-344.

Komatsuzaki N, Tsukahara K, Toyoshima H, Suzuki T, Shimizu N, Kimura T (2007). Effect of soaking and gaseous treatment on GABA content in germinated brown rice. J. Food Eng. 78:556-560.

Liu LL, Zhai HQ, Wan JM (2005). Accumulation of $\gamma$-aminobutyriac acid in giant-embryo rice grain in relation to glutamate decarboxylase activity and its gene expression during water soaking. Cereal Chem. 82:191-196.

Matsuda H, Tanaka A, Itakura A (2000). Immunology and hematology. In: Krinke GJ (ed) The laboratory rat, Academic Press, UK. pp. 437446.

Miura D, Ito Y, Mizukuchi A, Kise M, Aoto H, Yagasaki K (2006). Hypocholesterolemic action of pre-germinated brown rice in hepatoma-bearing rats. Life Sci. 79:259-264.

Moongngarm A, Saetang N (2010). Comparison of chemical compositions and bioactive compounds of germinated rough rice and brown rice. Food Chem. 122:782-788.

OECD (1998). Test No. 408: Repeated dose 90-day oral toxicity study in rodents. In OECD guidelines for the testing of chemicals, Section 4 : Health effects. Paris: OECD Publishing.
Oh $\mathrm{CH}$, Oh SH (2003). Brown rice extracts with enhanced levels of GABA stimulate immune cells. Food Sci. Biotechnol. 12:248-252.

Oh $\mathrm{CH}$, Oh SH (2004). Effects of germinated brown rice extracts with enhanced levels of GABA on cancer cell proliferation and apoptosis. J. Med. Food 7:19-23.

Oh SH, Moon YJ, Soh JR, Cha YS (2005). Effect of water extract of germinated brown rice on adiposity and obesity indices in mice fed a high fat diet. J. Food Sci. Nutr. 10:251-256.

Patil SB, Khan MK (2011). Germinated brown rice as value added rice product: A review. J. Food Sci. Technol. 48:661-667.

Rej R (1989). Aminotransferases in disease. Clin. Lab. Med. 9:667-687.

Roohinejad S, Omidizadeh A, Mirhosseini H, Saari N, Mustafa S, Yusof RM, Hussin ASM, Hamid A, Manap MYA (2010). Effect of pregermination time of brown rice on serum cholesterol levels of hypercholesterolemic rats. J. Sci. Food Agric. 90:245-251.

Seki T, Nagase R, Torimitsu M, Yanagi M, Ito Y, Kise M, Mizukuchi A, Fujimura N, Hayamizu K, Ariga T (2005). Insoluble fiber is a major constituent responsible for lowering post-prandial blood glucose concentration in pre-germinated brown rice. Biol. Pharm. Bull. 28:1539-1541.

Shallan MA, El-Beltagi HS, Mona, AM, Amera TM, Sohir NA (2010). Effect of amylose content and pre-germinated brown rice on serum blood glucose and lipids in experimental animal. Aust. J. Basic Appl. Sci. 4:114-121.

Shirai N, Suzuki H, Suzuki K, Ohitsubo K (2010). Effect of extruded polished, brown, and germinated brown rice on the behavior and plasma parameters of ICR mice. Food Sci. Technol. Res. 16:621-626.

Usuki S, Ariga T, Dasgupta S, Yu RK, Morikawa K, Nonaka S, Okuhara Y, Kise M (2008). Pre-germinated brown rice diet study: Acylated steryl glucoside (ASG) is a promising ingredient to improve hyperglycemia and neuropathy of diabetes. Diabetes 57(1):A229.

Watanabe M, Maemura K, Kanbara K, Tamayama T, Hayasaki H (2002). GABA and GABA receptors in the central nervous system and other organs. Int. Rev. Cytol. 213:1-47. 